University of Wollongong

Research Online

Faculty of Business - Papers (Archive)

Faculty of Business and Law

$1-1-2016$

How does corporate governance affect loan collateral? Evidence from Chinese SOEs and non-SOEs

Can An

Baoshang Bank Institute, ca927@uowmail.edu.au

Xiaofei Pan

University of Wollongong, xpan@uow.edu.au

Gary G. Tian

University of Wollongong, gtian@uow.edu.au

Follow this and additional works at: https://ro.uow.edu.au/buspapers

Part of the Business Commons

Research Online is the open access institutional repository for the University of Wollongong. For further information contact the UOW Library: research-pubs@uow.edu.au 


\title{
How does corporate governance affect loan collateral? Evidence from Chinese SOEs and non-SOEs
}

\author{
Abstract \\ We examine the effect of corporate governance on the collateral requirements for firms' bank loans in \\ China. We find that firms with lower excess control rights and other large shareholders face lower \\ collateral requirements, which is more pronounced in non-state-owned enterprises (SOEs) than in SOEs. \\ Regarding board characteristics, we find that smaller board size, more independent directors, separation \\ of the positions of CEO and chairman, and larger supervisory board size can reduce a firm's use of \\ collateral; the effect of all the preceding characteristics is more pronounced in SOEs. Overall, our research \\ suggests that, in China, corporate governance structures are able to affect bank-lending decisions in \\ respect of collateral requirements and that the influence depends on the controlling shareholder type and \\ associated agency problems.

\section{Disciplines} \\ Business

\section{Publication Details} \\ An, C., Pan, X. \& Tian, G. G. (2016). How does corporate governance affect loan collateral? Evidence from \\ Chinese SOEs and non-SOEs. International Review of Finance, 16 (3), 325-356.
}




\title{
How does corporate governance affect loan collateral? Evidence from Chinese SOEs and non-SOEs
}

\author{
Can $\mathrm{An}^{1}$, Xiaofei $\operatorname{Pan}^{2}$ and Gary Tian ${ }^{3 *}$ \\ ${ }^{1}$ Baoshang Bank, China \\ ${ }^{2}$ School of Accounting, Economics and Finance, University of Wollongong, Australia \\ ${ }^{3}$ Department of Applied Finance and Actuarial Studies, Macquarie University, Australia
}

\begin{abstract}
We examine the effect of corporate governance on the collateral requirements for firms' bank loans in China. We find that firms with lower excess control rights and other large shareholders face lower collateral requirements, which is more pronounced in non-SOEs than in SOEs. Regarding board characteristics, we find that smaller board size, more independent directors, separation of the positions of CEO and chairman, and larger supervisory board size can reduce a firm's use of collateral; the effect of all the preceding characteristics is more pronounced in SOEs. Overall, our research suggests that, in China, corporate governance structures are able to affect bank lending decisions in respect of collateral requirements, and that the influence depends on the controlling shareholder type and associated agency problems.
\end{abstract}

Keywords: Corporate Governance; Loan Collateral; Marketization; Ownership

JEL classifications: G21; G34

* Gary Tian is corresponding author. His email is gary.tian@deakin.edu.au. Can An’s email is tinacan@sina.cn. Xiaofei Pan’s email is xpan@uow.edu.au. 


\section{Introduction}

An evolving literature is beginning to focus on the agency conflicts faced by creditors in modern corporations (Anderson et al., 2004; Ashbaugh-Skaife et al., 2006; Boubakri and Ghouma, 2010; Lin et al., 2011). In principle, creditors face two types of agency conflict. The first is the conflict between creditors and firm managers. The separation between ownership and control leads to moral hazard problems and managerial self-serving behaviours, at the expense of shareholders and creditors. The second is the conflict between creditors and controlling shareholders. In firms with concentrated ownership, controlling shareholders have incentives to expropriate other investors, which incentives might be more significant when other investors are creditors (Shleifer and Vishny, 1997; Lin et al., 2011). These agency conflicts will reduce the expected value of cash flows to the firms and creditors, and increase the probability that the firms will face financial distress. As a firm's financial distress will increase the credit risks faced by creditors, creditors will require higher collateral to protect their interests in case of default (Menkhoff et al., 2006; Chen et al., 2013).

Meanwhile, another strand of literature has documented that effective governance mechanisms can mitigate the agency conflicts between creditors and manager/controlling shareholders, and thereby decrease the probability of financial distress and the associated credit risks faced by creditors (Anderson et al., 2004; Ashbaugh-Skaife et al., 2006). Consistent with this view, existing studies with cross-country evidence indicate that borrowers with better governance are rewarded with lower collateral requirements (e.g., Francis et al., 2012; Ge et al., 2012). However, Larcker et al. (2007) argue that existing studies do not show a consensus on the appropriate measurement of corporate governance indicators or of the number of corporate governance dimensions. This prompts a question: how do various governance mechanisms affect collateral requirements by creditors? In particular, the present study investigates the governance mechanisms through which the financial distress faced by firms and credit risks faced by creditors can be mitigated.

To answer this question, the relationship between corporate governance and the use of collateral in loan contracts is examined, using a sample of China's listed firms. This examination is motivated by the contrasting views on this subject which currently exist. On the one hand, it has been argued that the corporate governance of China's listed firms is designed simply to meet the regulatory requirements of the Chinese Securities Regulatory Commission (CSRC); and Liu (2006) argues that the corporate governance model adopted in China "has demonstrated many built-in weaknesses, which makes it less effective in 
disciplining management/controlling shareholders"1. On the other hand, a growing number of studies are beginning to document that corporate governance has become more effective, especially since 2005 when listed firms were required to complete the split-share structure reform (Huyghebaert and Wang, 2012; Liu et al., 2015). Thus, it is worthwhile to examine whether corporate governance is an effective monitoring mechanism to benefit creditors. In addition, rather than relying on the corporate governance index or country-specific governance (e.g., Francis et al., 2012; Ge et al., 2012), this paper explores the role of actual corporate governance practices within the two-tier board structure. Moreover, we are interested in examining the effect of governance, as measured by the excess control rights of controlling shareholders and other large shareholder ownership, on the use of collateral. We then further investigate how corporate governance interactively works with the ownership structure in affecting the use of collateral.

China's environment is an excellent laboratory in which to conduct this research for the following reasons. Firstly, China's listed firms exhibit concentrated ownership, and in many cases the controlling shareholder is the government, an individual or a family. This indicates that the controlling shareholder has substantial control over the firm, and potentially exposes creditors to severe expropriation and credit risks. However, the dominant agency conflicts vary across different types of owners. In state-owned enterprises (SOEs), the excess control rights held by the government are mainly driven by the incentive of the central government needing to separate SOEs from political interference and to decentralize decision rights to SOE managers (Fan et al., 2013). Nevertheless, insulated from the pyramid's top owners, SOE managers may be induced into severe managerial agency problems; so that creditors mainly face agency conflicts with firm management. In non-SOEs, controlling shareholders have a strong incentive to enhance their ultimate control through excess control rights, and to extract private benefits; while managerial agency problems are mitigated due to the fact that controlling shareholders usually have an incentive to monitor managers (Boubakri and Ghouma 2010; Cao et al., 2011); thus, creditors usually face agency conflicts with controlling shareholders in non-SOEs. Therefore, we are able to assess how better governance mechanisms interact with the type of ownership control to prevent financial distress, and how the collateral requirements of creditors are determined.

Secondly, we intend to shed light on the impact that the supervisory board has on the use of collateral, which is an important but unexplored aspect of corporate governance; although

\footnotetext{
${ }^{1}$ We thank the reviewer for pointing out this issue.
} 
the supervisory board in China still lacks the power to appoint and dismiss executive directors, in contrast to the corporate governance approach in Germany and Japan. Lastly, China also provides a unique opportunity for examining collateral requirements because of the government's tight control over interest rates during our sample period, which severely limited creditors' use of loan pricing to differentiate across borrowers with different levels of risk (Podpiera, 2006; Koivu, 2009) ${ }^{2}$. In developed markets, lenders are able to price loans through both interest rates and pledging collateral, so that they face a potential endogeneity issue where ownership structure, corporate governance and collateral requirements might have a joint impact on interest rates. This joint setting of interest rates and collateral requirements, in most other countries, may contaminate any observed causal relationship between ownership structure, corporate governance and collateral requirements. From this perspective, because our study is based on China, there will be less concern over endogeneity.

Briefly, the results reveal that governance mechanisms influence the use of collateral in China's listed firms, but that their effects differ according to ownership structure. Firstly, we find that the use of collateral is lower for firms in which controlling shareholders have lower excess control rights, or in which other large shareholders have larger ownership; and that this relationship is stronger in non-SOEs than in SOEs. In terms of a two-tier board structure, the results show that the use of collateral is lower for firms with a smaller board of directors, more independent directors, separate chairman and CEO positions, or a larger supervisory board; and that this relationship is stronger in SOEs than in non-SOEs. In addition, the expertise of the supervisory board helps firms to reduce the use of collateral, which is more significant for non-SOEs. These results confirm that different property rights and dominant agency problems exist between SOEs and non-SOEs. Therefore, internal corporate governance, such as a two-tier board structure, is more effective in reducing the use of collateral, by constraining the agency conflicts between creditors and management, in SOEs; while governance by other blockholders is more effective in reducing the use of collateral, by alleviating agency conflicts between creditors and controlling shareholders, in non-SOEs.

This research contributes to the literature in several ways. Firstly, fresh evidence proving how internal governance affects firms' use of collateral has here been presented. Extant evidence shows that corporate governance can prevent controlling shareholders from tunnelling, and can increase firm value (e.g. Bai et al., 2004). This research extends the

\footnotetext{
${ }^{2}$ This situation confirms the view that collateral is used to protect banks' interests from defaulting by borrowers. This also addresses the alternative view that high-quality borrowers are likely to pledge more collateral to enjoy a lower interest rate (Besanko and Thakor, 1987), because regulation of interest rates in China prevents them from doing this.
} 
literature by providing evidence that, when designing loan contracts, banks consider how internal governance can reduce their credit risks. Moreover, in a departure from the study by An et al. (2014), who examined the effect of ownership structure on the use of collateral, we move further to investigate how corporate governance interacts with ownership structure in affecting the use of collateral. Thus, we provide a complementary perspective to their study.

Secondly, our study provides additional evidence regarding the effectiveness of governance by a two-tier board system. This is a structure that consists of a board of directors and a supervisory board, and is a typical feature of the German and Japanese governance systems. Although Chinese supervisory boards resemble the German and Japanese governance structure, they have evolved over a relatively short period. Thus, the effectiveness in China of this two-tier board system remains an empirical question. Our results suggest that both the board of directors and the supervisory board are able to exert effective monitoring over the management and reduce the credit risks, thus reducing the use of collateral.

Finally, this paper also provides evidence of the determinants of collateral requirements in emerging markets. Menkhoff et al. (2006) and Menkhoff et al. (2012) find that the need for collateral is higher in less developed markets, and that borrowers can overcome the threat of a lack of collateral by substitutes such as third party guarantees and banking relationship. This paper complements their studies, and provides evidence of the effects of governance mechanisms, in Chinese listed firms, on the collateral required by banks; and that these effects are dependent on the type of ownership structure a firm has and its dominant agency problems.

The structure of the remainder of this paper is as follows. Section 2 reviews the Chinese institutional environment and then develops the hypotheses. Section 3 outlines the data and methodology. Section 4 reports the results of the empirical analyses. Section 5 provides additional tests; and Section 6 concludes the paper.

\section{Institutional background and hypothesis development}

\subsection{Institutional background}

\subsubsection{Ownership structure}

China began its transition from a centrally planned economy to a market-based economy in 1978. Under the communist system, China's governments collected revenue from SOEs and provided financing to those firms out of the state budget, so there was no need for risk management by banks in the use of collateral. When SOE reform began, the government tried to give autonomy to SOEs by linking rewards to performance and relinquishing its 
shareholding. That was followed, in the early 1980s, by the adoption of the "loan for (fiscal) grant" (bo gai dai) scheme, which aimed at increasing financial incentives and hardening the budget constraints faced by SOEs. A new phase of reform began in 1984, when the separation between management and ownership was further emphasized. In 1993, a new goal of establishing a modern enterprise system was set for SOE reform, which resulted in many SOEs being restructured into joint stock companies and being listed on the stock exchanges in Shanghai and Shenzhen, with shares sold to the public. However, governments at various levels still retained enough shares to exercise control. Some of the equity carved out of SOEs is now majority-owned by private investors, and there is a growing number of private firms that are now listed. During our sample period, non-SOEs comprise $44 \%$ of the sample.

Another characteristic of Chinese firms is that they usually have controlling shareholders. In some cases, the controlling shareholders own the firms directly as the largest shareholders. In other cases, controlling shareholders establish a pyramidal structure and own firms through the chain of ownership indirectly. In these firms, the control rights of the controlling shareholders are measured as the weakest link in the chain of ownership, and cash flow rights are measured by the product of ownership along the chain. For example, controlling shareholder (firm A) owns $70 \%$ of the shares in firm B, which in turn owns $50 \%$ of the shares in firm C. In this sense, firm A is the controlling shareholder of firm $\mathrm{C}$. The controlling shareholder (firm A) owns 50\% of control rights (which is its ownership) and $35 \%$ of cash flow rights of firm $\mathrm{C}$, while the largest shareholder of firm $\mathrm{C}$ is firm $\mathrm{B}$, which has $50 \%$ of ownership of firm C. In this case, the controlling shareholder's ownership is the same as that of the largest shareholder. In some other cases, the controlling shareholder's ownership can be different from the largest shareholder's ownership ${ }^{3}$. During our sample period, it was revealed that, on average, the controlling shareholder owns $37.1 \%$ of a firm, the largest shareholder owns $36.6 \%$ of a firm, and the second largest shareholder owns $8.46 \%$ of a firm; which indicates that the controlling shareholder has substantial control over the firm. In line with recent literature, we investigate the influence of corporate governance on the collateral requirements of China's listed companies, and how these effects vary based on the type of controlling shareholders.

\subsubsection{Two-tier board structure}

\footnotetext{
${ }^{3}$ One example of this is that firm A owns $40 \%$ of the shares in firm B, which in turn owns $50 \%$ of the shares in firm C. In this case, the controlling shareholder of firm C is firm A, which owns $40 \%$ of firm C. Another example is that firm A owns $70 \%$ of shares in both firm B and firm $\mathrm{C}$, which are both shareholders of firm D, with $40 \%$ ownership. In this case, the controlling shareholder of firm D is firm A, which owns $80 \%$ ownership of firm D.
} 
These listed firms are governed by two-tier boards that are similar to the German and Japanese corporate governance approach, and consist of a supervisory board and a board of directors. The Code of Corporate Governance for Listed Firms in China, published by the Chinese Securities Regulatory Commission (CSRC), expanded on Company Law by specifying the duties and responsibilities of directors in greater detail. Following this guideline, the board of directors was made accountable to shareholders, and was instructed to treat all shareholders equally and to take care of the interests of the firm's various stakeholders. In 2001, the independent director system was mandated by the CSRC, which required that at least one third of the board members of listed firms should be independent directors by June 30, 2003. The CSRC also strongly encouraged firms to separate the roles of chairman and CEO. However, China introduced the concept and culture of the modern corporation while extending the reforms of the state-owned economy. Although the responsibilities and duties of directors closely paralleled those in the West, it is doubtful whether they played a positive governance role in China, because the Chinese laws and guidelines are silent on who must propose directors; so that, in practice, large owners tend to appoint directors and their representatives to dominate the board (Wu et al., 2009).

According to Company Law, a listed company must also have a supervisory board that consists of no less than three members, including representatives of the shareholders of the company's employees and workers. According to Company Law, the supervisory board mainly carries out financial monitoring functions, which include examining the company's financial status and supervising the actions of the directors and managers to prevent any violations of laws, regulations, or the company's by-laws. It also states that supervisory members should have professional knowledge and work experience in accounting and law. A key difference between a board of directors and a supervisory board is that supervisors of the company cannot concurrently serve as its directors, managers, or financial officers, so that they are expected to oversee the performance of the directors and senior management in a relatively impartial manner (Dahya et al., 2003; Firth et al., 2007a, b; Ding et al., 2009 and Ding et al. (2010).

Although the supervisory board in China still lacks the power to appoint and dismiss executive directors, unlike in the German and Japanese approach to corporate governance, the latest Company Law Amendment 2005 largely addresses several important constraints that prevented supervisory boards from functioning properly. Firstly, supervisory boards now do have the power to recommend the dismissal of directors and members of top management who have been convicted of crimes, and to sue directors and members of top management 
who commit fraud. Secondly, supervisors were already allowed to attend board meetings; but the latest amendment gives them the right to ask questions and make suggestions. Furthermore, supervisory boards now have the right to submit proposals to shareholder meetings. Finally, when the board of supervisors discovers something unusual in the operation of the company, it can conduct an investigation into the operating situation, with the company bearing the expense.

Overall, the present paper adds to the literature by means of a detailed investigation of the impact of internal governance on collateral requirements, which has not been previously examined.

\subsubsection{Banking structure and bank lending policies}

In the early 1980s, the government established four wholly state-owned banks (the Big Four), which took control of all the lending functions of the People's Bank of China (the central bank). Later, in 1994, three wholly state-owned policy banks were established and took over policy lending from the Big Four banks. By 1996, joint stock commercial banks and city banks had begun to emerge.

Originally, bank loans mainly took the form of credit loans granted at low interest rates and without any guarantees or collateral. This, among other factors, resulted in a higher ratio of non-performing loans (NPLs). As the market-oriented economy developed, banks became increasingly aware of loan risk, and from the 1990s they increasingly demanded guarantees or collateral. Indeed, according to a survey of 13 domestic banks between 2000 and 2005, the average collateral for secured loans - of which land or buildings became the most acceptable form - increased from $22 \%$ to $32 \%$ of all loans granted (Yang and Qian, 2008). Banks also demanded the equivalent value of fixed assets as collateral before granting loans, especially to privately controlled firms (Yeung, 2009). Meanwhile, before March 1998, the People's Bank of China recommended the interest rate for lending by commercial banks, and allowed fluctuations around this recommended standard rate. Later, in October 2004, the ceiling rate was relaxed, but the floor on lending rates remains in place. It was not until July 20, 2013, following further interest rate reform, that the Chinese Central Bank freed up interest rates; and since then commercial banks have acquired much greater autonomy in setting lending and deposit rates.

In addition, there was discrimination in bank loans in favour of SOEs relative to private firms (Cull and $\mathrm{Xu}, 2003$ ), with state-owned banks often lending to SOEs for political, employment and taxation purposes rather than for profitability (Brandt and Li, 2003). As Yeung (2009) discusses, for these banks (the Big Four SOCBs, policy banks, joint stock 
commercial banks, and city banks), the decision of whether to grant loans was often determined by unofficial assessment criteria and majority state ownership of financial systems. SOEs tended to receive loans from the Big Four banks because of their state ownership, without pledging the necessary collateral; while private firms were expected to pledge collateral by securing their fixed assets to the equivalent value of the collateral required. This was a rational decision made by banks to bias their lending against private firms, based on the higher risks involved and higher costs of transaction and risk evaluation.

Since the economic reform of 1978, the evolution of the private sector in China has been significant. According to the Bureau of Statistics, up until December 2011 the output of the private sector accounted for more than $50 \%$ of GDP and provided more than $90 \%$ of the job opportunities; but discrimination against lending to private firms in China, as described above, has limited the growth of bank loans to private firms (Li et al., 2008). Extant literature investigates the lending practices towards private firms in China, and argues that poor profitability and higher credit risks among private firms are the main reasons for discrimination in bank loans and loan standards (Brandt and Li, 2003; Firth et al., 2009).

When making lending decisions, banks are also concerned about borrowers' governance structure, as better governance structure is effective in protecting the interests of banks. Specifically, at the G20/OECD forum on April 10, 2015, Mr Yao Feng, the vice president of the China Association for Public Companies (CAPCO), emphasized that the governance structure of listed firms has been improved and is effective in protecting the interests of all investors ${ }^{4}$. Anecdotal evidence also suggests that loan officers are concerned about the governance structure of borrowers even after collateral loans are granted ${ }^{5}$; and that a better governance structure helps firms to obtain loans with lower collateral requirements ${ }^{6}$.

\subsection{Development of hypotheses}

In this section, we discuss how different aspects of corporate governance affect the use of collateral; and we particularly focus on ownership structure and the two-tier board structure as proxies for corporate governance.

One feature of ownership structure in China is the existence of a controlling shareholder through a pyramidal structure. As noted by existing studies, these controlling shareholders hold significant control rights in excess of cash flow rights; and this divergence between control rights and cash flow rights induces moral hazards and adverse selection activities by

\footnotetext{
${ }^{4}$ Source access: http://stock.hexun.com/2015-04-15/174961155.html

${ }^{5}$ Source access: http://www.hinews.cn/news/system/2009/02/16/010415723.shtml

${ }^{6}$ Source access: http://news.10jqka.com.cn/20120910/c529392647.shtml
} 
controlling shareholders (Cleassens et al., 2002). Controlling shareholders may use their powerful position to extract resources for their private benefit at the cost of other investors, while suffering limited consequences for such behaviour; and this incentive to expropriate other investors becomes more severe when controlling shareholders' excess control rights become larger (Lin et al., 2011). This severe expropriation will result in a higher probability of financial distress or bankruptcy, as well as associated costs; all of which are detrimental to creditors. As creditors face higher credit risks, and incorporate this expectation into their lending decisions, they are more likely to use higher requirements as a protection against the possibility of a borrower defaulting.

Another feature of ownership structure in China is the existence of multiple large shareholders. Noticing that controlling shareholders have an incentive to practise expropriation, existing studies have suggested that a structure involving multiple large shareholders is effective in mitigating such behaviour, because these large shareholders may compete for control and monitor the controlling shareholders (Bennedsen and Wolfenson, 2000; Laeven and Levine, 2008). An active takeover market does not exist in China; but other large shareholders, apart from the controlling shareholder, can challenge opportunistic controlling shareholders. Other large shareholders may constitute a serious obstacle to expropriation activities by the controlling shareholder because of their desire to protect their own interests and reduce the probability of financial distress (Berkman et al., 2009; Huybhebaert and Wang, 2012; Yeh and Woidtke, 2005). In the case of presence of multiple large shareholders, banks will face lower credit risks and thus require lower collateral.

Furthermore, expropriation by a controlling shareholder is more evident in non-SOEs. In these firms, the controlling shareholder is usually an individual or a family, who uses the pyramid structure to enhance their ultimate control and extract resources for their private benefit, so that the main agency conflicts faced by banks involve the controlling shareholders. Consequently, banks will require higher collateral for non-SOEs with higher excess control rights or with lower ownership by multiple large shareholders. However, in the case of SOEs, Fan et al. (2013) argue that the excess control rights of the government mainly results from the intention of the government to decentralize decision rights to firm managers, and to reduce government interference as well as political costs; thus self-dealing behaviour by managers becomes more severe and banks face agency conflicts with management. Therefore, the influence of excess control rights and ownership by multiple large shareholders on the use of collateral is weaker in SOEs. Thus we form the following hypotheses: 
Hla: Excess control rights are positively related to the use of collateral, and this positive relationship is more pronounced in non-SOEs than in SOEs.

H1b: Ownership by multiple large shareholders is negatively related to the use of collateral, and this negative relationship is more pronounced in non-SOEs than in SOEs.

We next consider the effect of the two-tier board structure. In terms of the board of directors, board size is one of the factors that affect the effectiveness of the board's monitoring function. Compared to small boards, large boards are less effective in communication and more likely to be controlled by powerful shareholders (Yermack, 1996). Firth et al. (2007a) also argue that a large board may reduce the informativeness of earnings, which decreases its ability to monitor the management. In this sense, banks may consider that firms with larger boards lose their ability to exert efficient monitoring, causing a higher credit risk, so that creditors are more likely to require them to pledge higher collateral.

In addition, agency theorists consider a board's independence to be a crucial aspect of its monitoring role, which serves the best interests of other investors (Fama and Jensen, 1983; Liu et al., 2015). In the context of China, independent directors are supposed to ensure that financial decisions are made to maximize firm value and should not result in earnings or cash flows that are biased toward the controlling shareholders (CSRC, 2002). Independent directors are thus expected to promote good governance, due to their positive behavioural motivation and reputation concern (Fama and Jensen, 1983; Shan and McIver, 2011; Shan, 2013), and to be effective in mitigating opportunistic behaviour by management (Liu et al., 2015). Thus, board independence is able to protect firms from financial distress and reduce the credit risk faced by banks, and in turn reduce the use of collateral.

Existing studies have also documented that separating the positions of CEO and chairman can increase the effectiveness of the board's monitoring of management. Liu and $\mathrm{Lu}$ (2007) provide empirical evidence that the effectiveness of board monitoring becomes weaker when the CEO is also the chairman. Accordingly, if firms have a dual CEO and chairman, managerial self-dealing behaviour will be more severe, which leads to a higher probability of financial distress and credit risks, and to the need for firms to pledge more collateral to obtain loans.

As the characteristics of the board are associated with the monitoring of managerial behaviour, based on our discussion above about the dominant agency conflicts between SOEs and non-SOEs, we form the following hypotheses:

H2a: Board size is positively associated with the use of collateral, and this positive relationship is more pronounced in SOEs than in non-SOEs. 
H2b: The proportion of independent directors is negatively associated with the use of collateral, and this negative relationship is more pronounced in SOEs than in non-SOEs.

H2c: Having a dual CEO/chairman is positively associated with the use of collateral, and this positive relationship is more pronounced in SOEs than in non-SOEs.

The existence of both a board of directors and a supervisory board in China is usually referred as a two-tier board structure. According to the Company Law (2003), the main objective of the supervisory board is to examine the financial statements and monitor the behaviour of executives and directors of boards, which may help to improve the quality of firms' accounting. Unlike boards of directors, the supervisory boards represent firm workers and minority shareholders, who are free of the control of controlling shareholders; and executives or directors cannot be members of the supervisory boards. In this sense, a larger supervisory board is more likely to successfully protect the interests of stakeholders, and these stakeholders value supervisory boards and appreciate their activities. In particular, Firth et al. (2007a) show that large supervisory boards result in an improvement in the quality of accounting information. If the large supervisory board of a borrower can effectively exercise its monitoring role and decrease the credit risks faced by banks, it is then expected to reduce the use of collateral in their loan contracts.

Furthermore, the professional knowledge and working experience of supervisors in areas such as law and accounting should be able to improve the governance of a supervisory board. Dahya et al. (2003) point out that supervisors are expected to have the necessary competencies in terms of knowledge and experience to perform their monitoring role. If a supervisory board that has more supervisors with the appropriate professional knowledge or working experience improves corporate governance, this is expected to reduce credit risk and to be negatively related to the use of collateral.

As the supervisory board is able to exert monitoring over the management, we expect that the effect of the characteristics of the supervisory board on the use of collateral will be more pronounced in SOEs. Therefore, we form the following hypotheses:

H3a: Supervisory board size is negatively associated with the use of collateral, and this negative relationship is more pronounced in SOEs than in non-SOEs.

$H 3 b$ : The proportion of supervisors with professional knowledge or working experience on the supervisory board is negatively associated with the use of collateral, and this negative relationship is more pronounced in SOEs than in non-SOEs.

\section{Data and methodology}

\subsection{Sample selection}


The initial sample consists of all firms listed on the Shanghai and Shenzhen Stock Exchanges for the years 2007 to 2009 . The bank loan sample is manually collected from the footnotes of the annual reports of listed firms. To be included in the sample, the footnote should contain detailed information on the bank loans, such as loan maturity (long term or short term), the type of bank loan (guaranteed, collateralized, or unsecured), and the amount of loans for each type. The present research also used the annual reports to identify the professional supervisors. Other corporate financial data used in this research are gathered from the China Stock Market and Accounting Research (CSMAR) database.

Initially, there are 4,969 firm-year observations available on the CSMAR database from 2007 to 2009. Table 1 describes the sample selection process. First, 523 observations with no outstanding loans were eliminated; and of the remaining 4,446 observations, 18 observations in the financial industry were deleted. Then 109 observations were eliminated because the type of bank loan cannot be identified in the financial reports; and a further 170 observations with insufficient data to calculate financial data were also deleted. Moreover, an additional 387 ST or ${ }^{*}$ ST firm-year observations ${ }^{7}$ were also eliminated, as were 568 observations that had insufficient data to calculate corporate governance data. The final sample consisted of 3,194 firm-year observations from 2007 to 2009. In addition, as we use the one-year lagged value of all independent variables for the empirical analysis, we also collected data for these independent variables for 2006, which includes 3,194 firm-year observations.

Table 1. Sample selection process

\begin{tabular}{ll}
\hline Sample selection & Observations \\
\hline Firm-year observations from 2007 to 2009 & 4,969 \\
Less: & 523 \\
Firms without outstanding loans & 18 \\
Firms from financial industry & 109 \\
Type of loan cannot be identified & $170+568$ \\
Firms with missing information & 387 \\
Firms flagged with ST or *ST & 3,194 \\
Total observations & \\
\hline
\end{tabular}

\subsection{Estimation model and variable definition}

According to the hypotheses presented in the previous section, this research estimates the following models for regression analysis:

\footnotetext{
${ }^{7}$ ST stands for Special Treatment, and refers to the listed firms that have already had negative net profits for two consecutive years. ${ }^{*}$ ST refers to the listed firms that have already had negative net profits for three consecutive years and thus have the probability of being delisted from the stock exchanges.
} 


$$
\begin{aligned}
\text { Collateral }_{i t}= & \beta_{0}+\beta_{1} \text { Governance }_{i t-1}+\beta_{2} \text { Governace }_{i t-1} * \text { NonSOE }_{i t}+\beta_{3} \text { NonSOE }_{i t} \\
& +\beta_{4} \text { Ownership }_{i t}+\beta_{5} \text { Guarantee }_{i t-1}+\beta_{6} \text { Size }_{i t-1}+\beta_{7} A E_{i t-1}+\beta_{8} \text { B }_{\text {M }} \text { it }-1_{i t} \\
& +\beta_{9} \text { ROA }_{i t-1}+\beta_{10} \text { Leverage }_{i t-1}+\beta_{11} \text { LTDebt }_{i t-1}+\beta_{12} \text { Tangibility }_{i t-1} \\
& +\beta_{13} \text { Liquidity }_{i t-1}+\beta_{14} \text { Volatility }_{i t-1}+\text { Year }+ \text { Industry }+\varepsilon_{i t}
\end{aligned}
$$

where Collateral is the percentage of total loans collateralized for firm $i$ in year $t$. In the empirical analysis, we use the percentage of collateralized loans over total loans outstanding as a measure for firms' use of collateral, which is consistent with Chen et al. (2013) ${ }^{8}$. In particular, the amount of collateralized loans is the sum of both pledged loans and mortgage loans, and firms' use of collateral is defined as follows:

\section{Collateral $=$ Collateralized loans $/$ Total loans outstanding}

Governance represents a set of variables that we employ as the proxies for ownership and governance. To test our main hypotheses, we include each of these variables in equation (1) separately. In particular, the proxies for ownership include NonSOE, Execss and Top2_10. NonSOE is a dummy variable equal to 1 for non-SOEs and 0 for SOEs. Consistent with Chen et al. (2011), a firm is identified as a non-SOE when its controlling shareholder is an individual or a non-state entity, and other firms are defined as SOEs. Excess is the deviation between control rights and cash flow rights of the controlling shareholders, consistent with Claessens et al. (2002). Top2_10 is the percentage of shares held by the second to the tenth largest shareholders.

We measure the two-tier board structure governance by looking at five aspects: Board is the $\log$ of the total number of directors on the board; Indep is the ratio of independent directors to the total number of directors on the board; Duality is a dummy variable equal to 1 if the CEO is also the chairman and 0 otherwise; SBsize is the log of the number of supervisors on the supervisory board; SBexpert is the ratio of supervisors on the supervisory board with professional knowledge or work experience in areas such as law and accounting. In line with existing studies (Menkhoff et al., 2012; Chen et al., 2013), a set of control variables, as well as year and industry fixed effects, are also included in the regression; and the detailed information and definitions of all variables used in this study are presented in Table 2 below.

Table 2. Variable definition

\begin{tabular}{ll}
\hline Variable & Definition \\
\hline Collateral & The percentage of total loans that are collateralized \\
NonSOE & A dummy variable equal to 1 for non-SOEs and 0 otherwise. \\
\hline
\end{tabular}

\footnotetext{
${ }^{8}$ As argued by Chen et al. (2013), the ideal proxy for the use of collateral is to incorporate the information on collateral value. However, due to the unavailability of this information, we follow Chen et al. (2013) and use the collateral loan ratio as the proxy in this study.
} 


\begin{tabular}{ll}
\hline Excess & Control-ownership deviation by the controlling shareholder \\
Top2_10 & The sum of ownership held by the second to the 10th largest shareholders \\
Board size (Board) & Log of the total number of directors on the board \\
Independence (Indep) & The percentage of independent directors on the board \\
Duality & A dummy variable equal to 1 if the CEO is also the Chairman of the board \\
SB size & Log of the total number of members on the supervisory board \\
SB expertise & The percentage of supervisors on the supervisory board who have \\
professional knowledge or work experience in areas such as law and & accounting \\
Ownership & Ownership held by the largest shareholder \\
Guarantee & Percentage of total loans that are guaranteed \\
Firm size (Size) & Log of firm total assets \\
Abnormal earnings (AE) & Earnings per share in year t+1 minus earnings per share in year t, divided by \\
& the share price in year t \\
B/M & Book to market value \\
Return on assets (ROA) & Net income / Total assets \\
Leverage & Total debts / Total assets \\
LDebt & Long-term debt / Total loans \\
Tangibility & Fixed assets / Total assets \\
Liquidity & Cash and cash equivalents / Total assets \\
Age & The log of the years since firm is established \\
Sales & Total sales / Total assets \\
Segment & The number of business segments \\
\hline
\end{tabular}

\subsection{Estimation methods}

In the empirical analysis, one concern about our estimation on the relationship between corporate governance, ownership structure, and the use of collateral, is the issue of endogeneity. For example, firms required by banks to provide higher collateral may have the incentive to adjust their ownership structure or board structure, suggesting the existence of reverse causality. To address this issue, we use a simultaneous equation system in which the use of collateral, ownership structure, and board structures are endogenously determined. In addition, since firm profitability and guaranteed loans can also be endogenously determined by a set of control variables similar to that used in the collateral equation, we further include two equations in our simultaneous equation system where firm profitability and guaranteed loans are used as dependent variables. In particular, these equations are expressed as follows:

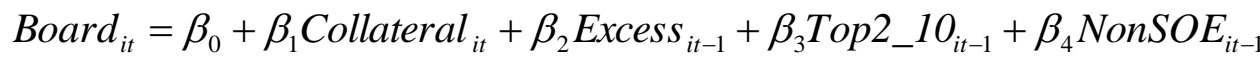

$$
\begin{aligned}
& +\beta_{5} \text { Indep }_{i t-1}+\beta_{6} \text { Duality }_{i t-1}+\beta_{7} \text { SBsize }_{i t-1}+\beta_{8} \text { SBexpert }_{i t-1} \\
& +\beta_{9} A E_{i t-1}+\beta_{10} \text { Size }_{i t-1}+\beta_{11} \text { Segment }_{i t}+\text { Year }+ \text { Industry }+\varepsilon_{i t} \\
& \text { Indep }_{i t}=\beta_{0}+\beta_{1} \text { Collateral }_{i t}+\beta_{2} \text { Excess }_{i t-1}+\beta_{3}{\text { Top } 2 \_10_{i t-1}}+\beta_{4} \text { NonSOE }_{i t-1} \\
& +\beta_{5} \text { Board }_{i t-1}+\beta_{6} \text { Duality }_{i t-1}+\beta_{7} \text { SBsize }_{i t-1}+\beta_{8} \text { SBexpert }_{i t-1} \\
& +\beta_{9} \text { Ownership }_{i t}+\beta_{10} \text { Size }_{i t-1}+\beta_{11} \text { Age }_{i t}+\text { Year }+ \text { Industry }+\varepsilon_{i t}
\end{aligned}
$$




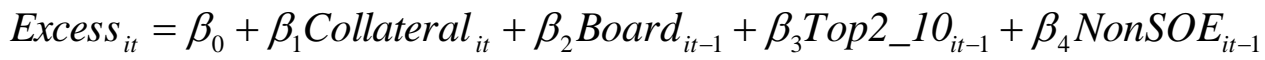

$$
\begin{aligned}
& +\beta_{5} \text { Indep }_{i t-1}+\beta_{6} \text { Duality }_{i t-1}+\beta_{7} \text { SBsize }_{i t-1}+\beta_{8} \text { SBexpert }_{i t-1} \\
& +\beta_{9} \text { Tangibility }_{i t-1}+\beta_{10} \text { Size }_{i t-1}+\beta_{11} \text { LTDebt }_{i t-1}+\beta_{12} \text { Excessmean }_{i t} \\
& + \text { Year }+ \text { Industry }+\varepsilon_{i t} \\
& \text { ROA }_{i t}=\beta_{0}+\beta_{1} \text { Collateral }_{i t}+\beta_{2} \text { Excess }_{i t-1}+\beta_{3} \text { Top2_10 }{ }_{i t-1}+\beta_{4} \text { NonSOE }_{i t-1} \\
& +\beta_{5} \text { Indep }_{i t-1}+\beta_{6} \text { Duality }_{i t-1}+\beta_{7} \text { SBsize }_{i t-1}+\beta_{8} \text { SBexpert }_{i t-1}+\beta_{9} \text { Ownership }_{i t} \\
& +\beta_{10} \text { Size }_{i t-1}+\beta_{11} \text { Sales }_{i t-1}+\beta_{12} \text { LagROA }_{i t}+\text { Year }+ \text { Industry }+\varepsilon_{i t}
\end{aligned}
$$

In each of the above equations, other endogenous variables are included as independent variables to account for reverse causality. Following the discussion by Bhagat and Bolton (2008), instrument variables for each endogenous variable are also included in the equations. Specifically: Segment, defined as the number of business segments, is used as the instrument variable in equation (2); Age, defined as the log of years since firm was established, is used as the instrument variable in equation (3); Excessmean, defined as the industry average Excess, is used as the instrument variable in equation (4); Topmean, defined as the industry average Top2_10, is used as the instrument variable in equation (5); LagGuarantee, defined as the lagged guaranteed loan, is used as the instrument variable in equation (6); and LagROA, defined as the lagged $R O A$, is used as the instrument variable in equation (7). The selection of these instrument variables is motivated by existing empirical studies (Linck et al., 2008; Jackling and Johl, 2009; Lin et al., 2011). In the next section, where we conduct the regression analysis to examine the effects of corporate governance on the use of collateral, the simultaneous equation systems include the equations where the use of collateral and the relevant corporate governance variables are treated endogenously. These simultaneous equation systems are estimated using the three-stage least square (3SLS) method, which takes the cross-equation error correlation into account to improve the estimation efficiency of a large sample. We also conduct over-identification tests (reporting p-values) to examine the validity of the instrument variables. 
Moreover, borrowers with a certain ownership structure and board structure might have other firm-specific characteristics, unaccounted for in our model, that affect ownership structure, board structure and the use of collateral jointly, and may bias our results. Although it is difficult to rule out the endogeneity issue completely, we address this issue in two ways, by estimating equation (1) using both the firm fixed effect model and system GMM. In particular, the firm fixed effect/GMM allows us to account for time-invariant, common unobservable or omitted firm-specific characteristics that might affect ownership structure, board structure, and the use of collateral.

To save space and focus on our main discussion, we report only the estimation results of equation (1) of our simultaneous equation system; and estimation results of other equations are available upon request ${ }^{9}$. We also report the estimation results of equation (1) using the firm fixed effect and system GMM for robustness.

\subsection{Summary statistics}

Table 3 lists the summary statistics of variables for the full sample. Panel A presents descriptive statistics on the use of collateral; Panels B and C show the characteristics of ownership structure and corporate governance proxies; and Panel D presents the summary statistics of control variables to be used in the regression analysis. Panel A shows that, on average, about $36 \%$ of total loans require collateral. As Panel B shows, non-SOEs comprise $44.3 \%$ of the sample. In addition, Panel B shows that the average excess control right is $6.2 \%$, and that other large shareholders are holding $19.2 \%$ of ownership. Panel C shows that the average board size was 9.2 and the median was 9; while the proportion of independent directors on the board has a mean of $38.3 \%$; and about $15.9 \%$ of the CEOs were also the chairman of the board. Panel $\mathrm{C}$ also shows that the average (median) of supervisory board size is 3.9 (3), and that the proportion of supervisors on the supervisory board with professional knowledge or work experience has a mean of $20.0 \%$.

Table 3. Summary statistics

\begin{tabular}{lllllll}
\hline Variables & $\mathrm{N}$ & Mean & Median & $5^{\text {th }}$ & $9^{\text {th }}$ & Std. Dev. \\
\hline $\begin{array}{l}\text { Panel A: Collateral loan ratio } \\
\text { Collateral }\end{array}$ & 3194 & $36.0 \%$ & $27.1 \%$ & 0 & 1 & $34.2 \%$ \\
$\begin{array}{l}\text { Panel B: Ownership structure } \\
\text { NonSOE }\end{array}$ & 3194 & $44.3 \%$ & 0 & 0 & 1 & $50.3 \%$ \\
Excess & 3194 & $6.2 \%$ & 0 & 0 & $23.1 \%$ & $8.6 \%$ \\
$\begin{array}{l}\text { Top2_10 } \\
\text { Panel C: Corporate governance }\end{array}$ & 3194 & $19.2 \%$ & $17.0 \%$ & $2.5 \%$ & $43.4 \%$ & $13.0 \%$ \\
Board & 3194 & 9.2 & 9 & 6 & 13 & 1.9
\end{tabular}

\footnotetext{
${ }^{9}$ For readers' reference, we present the estimation results of other equations in the Appendix. These equations correspond to the collateral equation in column 6 of Table 6 , where we consider all endogenous variables.
} 


\begin{tabular}{lllllll} 
Indep & 3194 & $38.3 \%$ & $33.3 \%$ & $33.3 \%$ & $55.6 \%$ & $9.4 \%$ \\
Duality & 3194 & $15.9 \%$ & 0 & 0 & 1 & $36.6 \%$ \\
SB size & 3194 & 3.9 & 3 & 3 & 6 & 1.3 \\
SB expertise & 3194 & $20.0 \%$ & $20.0 \%$ & 0 & $66.7 \%$ & $21.4 \%$ \\
Panel D: Control variables & & & & & & \\
Ownership & 3194 & $35.53 \%$ & $33.48 \%$ & $13.93 \%$ & $62.38 \%$ & $15.22 \%$ \\
Guarantee & 3194 & $39.7 \%$ & $35.8 \%$ & 0 & 1 & $33.8 \%$ \\
Size & 3194 & 21.6 & 21.5 & 20.1 & 23.5 & 1.1 \\
AE & 3194 & $0.3 \%$ & 0 & $-5.2 \%$ & $7.5 \%$ & $6.6 \%$ \\
B/M & 3194 & $53.0 \%$ & $48.2 \%$ & $18.0 \%$ & $102.9 \%$ & $26.2 \%$ \\
ROA & 3194 & $3.4 \%$ & $3.5 \%$ & $-6.4 \%$ & $12.4 \%$ & $8.7 \%$ \\
Leverage & 3194 & $24.0 \%$ & $23.2 \%$ & $2.3 \%$ & $48.7 \%$ & $14.4 \%$ \\
LDebt & 3194 & $30.3 \%$ & $20.2 \%$ & 0 & $96.5 \%$ & $31.7 \%$ \\
Tangibility & 3194 & $27.8 \%$ & $24.8 \%$ & $1.9 \%$ & $61.8 \%$ & $18.5 \%$ \\
Liquidity & 3194 & $16.7 \%$ & $13.7 \%$ & $2.9 \%$ & $40.0 \%$ & $12.3 \%$ \\
\hline
\end{tabular}

\section{Empirical results}

\subsection{Univariate tests}

To provide some preliminary information, Table 4 presents univariate comparisons of the collateralized loan ratio as well as of ownership and governance characteristics of SOEs and non-SOEs. Firstly, the average collateralized loan ratio is $28.7 \%$ for SOEs, which is significantly lower than the $45.1 \%$ for non-SOEs. In addition, the excess control rights of the controlling shareholder in non-SOEs are significantly higher than in SOEs. The results also clearly suggest that non-SOEs have more concentrated ownership by other large shareholders, with an average of $22.9 \%$, while the average is $16.3 \%$ for SOEs. In terms of a two-tier board structure, the average board size in firms controlled by SOEs is 9.6, which is significantly larger than the 8.8 for non-SOEs. Table 4 also shows that the SOEs are less likely to have a dual CEO/chairman, with an average of $10.5 \%$, while the average for nonSOEs was $22.8 \%$. In addition, SOEs have a similar proportion of independent directors to non-SOEs, with means of $38.1 \%$ and $38.5 \%$, respectively. In terms of a supervisory board, the non-SOEs have a significantly smaller supervisory board, with a size of 3.6 persons, while SOEs have a typical size of 4.3 persons on average. In addition, non-SOEs have a smaller proportion of supervisors with professional knowledge or work experience on the supervisory board than do SOEs, with an average of $17.3 \%$ and $22.2 \%$, respectively.

Overall, this section finds that the governance characteristics differed across firms classified by types of controlling shareholders. Thus, in the following empirical analysis, we are also interested in examining the effects of ownership structure and corporate governance on the use of collateral in SOEs and non-SOEs.

Table 4. Univariate tests between SOEs and non-SOEs

\begin{tabular}{|c|c|c|c|}
\hline Variables & SOEs & Non-SOEs & Difference (t-test) \\
\hline
\end{tabular}




\begin{tabular}{llll}
\hline Collateral & $28.7 \%$ & $45.1 \%$ & $16.37 \% * * *(13.68)$ \\
Excess & $3.7 \%$ & $9.3 \%$ & $5.62 \% * * *(9.10)$ \\
Top2_10 & $16.3 \%$ & $22.9 \%$ & $6.6 \% * * *(14.66)$ \\
Board size & 9.6 & 8.8 & $-0.8 * * *(-12.30)$ \\
Independence & $38.1 \%$ & $38.5 \%$ & $0.4 \%(1.31)$ \\
Duality & $10.5 \%$ & $22.8 \%$ & $-12.3 \%$ N $^{* * *}(9.27)$ \\
SB size & 4.3 & 3.6 & $-0.7 * * *(-15.37)$ \\
SB expertise & $22.2 \%$ & $17.3 \%$ & $-4.9 \% * * *(-6.48)$ \\
\hline
\end{tabular}

*** indicates significance at the $1 \%$ level.

\subsection{Multivariate tests}

\subsubsection{Ownership governance and the use of collateral}

Before running the regressions, the correlation matrix and the variance inflation factor (VIF) are checked; and this shows that absolute values of all the correlation coefficients are less than 0.397 and the VIF is less than 2.57 for all the regressions (untabulated), which implies that multi-collineality would not be a critical issue here.

Table 5 provides the empirical results of the collateral equation from our simultaneous equation system on the association between ownership and the use of collateral. In columns 1 and 2, we consider the influence of Excess and Top2_10 separately. The results in column 1 show that the estimated coefficient of Excess is 0.10 , which is statistically significant at the $5 \%$ level (t-value is 2.04). We also observe that the coefficient of Excess $*$ NonSOE is positive and statistically significant at the 5\% level (t-value is 2.08). These results support our hypothesis H1a, that the larger control-ownership wedge of the controlling shareholders is expected to be associated with a higher risk of expropriation and higher collateral requirements by banks; and that this effect is more pronounced in non-SOEs. In addition, higher concentration of ownership held by other large shareholders is able to reduce the risk of expropriation and thus reduce the use of collateral in their loan contracts.

In column 2 we consider the effect of ownership concentration held by other large shareholders on the use of collateral. Specifically, we find that the estimated coefficients of Top2_10 and Top2_10*NonSOE are -0.50 and -0.28 , with both significant at the $1 \%$ levels (tvalues are -6.76 and -2.86 , respectively).These results are consistent with our expectation and support our hypothesis $\mathrm{H} 1 \mathrm{~b}$, that ownership by other large shareholders will mitigate the risk of expropriation and lead to lower collateral requirements; and that this mitigating effect is more significant in non-SOEs. In the last column, we put both variables together, and the estimated results are quite similar to those reported in both columns 1 and 2 .

We also observe that the estimated coefficient of NonSOE in column 1 is 0.16 , significant at the $1 \%$ level, indicating that the use of collateral is significantly higher for non- 
SOEs than for SOEs. This result is consistent with An et al. (2014). The estimated coefficients of some control variables exhibit the expected signs. For example, there is a negative association between the guarantee requirements (Guarantee) and the use of collateral; which suggests that a loan guarantee acts like a collateral substitute and allows a lender to enforce collateral-free loans. The likelihood of using collateral also decreases with the size of the borrower (Size), firm profitability (ROA), tangibility (Tangibility), and liquidity (Liquidity); which is consistent with Almeida and Campello (2007). In addition, the leverage levels (Leverage) and term structure (LDebt) are both positively related to the use of collateral. The present research finds no strong support for the signalling hypothesis, because the relevant variable $(A E)$ shows a negative sign, which is different from Barclay and Smith (1995). This research also does not find a postulated positive relationship between growth opportunities $(B / M)$ and the proportion of secured debt. Given an inverse relationship between growth opportunities and indebtedness in the Chinese context (Bhabra et al., 2008), an inverse relationship between the former and the secured debt ratio may be interpreted as a general tendency for growing firms to decrease the size of debt financing, especially collateralized loans.

Table 5. Effect of ownership on the use of collateral

\begin{tabular}{|c|c|c|c|}
\hline \multirow[t]{2}{*}{ Dependent variable } & \multicolumn{2}{|c|}{ Collateralized loan ratio } & \multirow[b]{2}{*}{3} \\
\hline & 1 & 2 & \\
\hline Excess & $0.10 * *(2.04)$ & & $0.08 *(1.83)$ \\
\hline Excess*NonSOE & $0.15 * *(2.08)$ & & $0.03 * *(2.18)$ \\
\hline Top2_10 & & $-0.50 * * *(-6.76)$ & $-0.22 * * *(-2.88)$ \\
\hline Top2_10*NonSOE & & $-0.28 * * *(-2.86)$ & $-0.30 * * *(-3.01)$ \\
\hline NonSOE & $0.16^{* * *}(9.50)$ & $0.23 * * *(9.96)$ & $0.24 * * *(8.66)$ \\
\hline Ownership & $-0.18 * * *(-4.11)$ & $-0.28 * * *(-6.12)$ & $-0.27 * * *(-5.88)$ \\
\hline Guarantee & $-0.67 * * *(-33.69)$ & $-0.67 * * *(-34.38)$ & $-0.67 * * *(-34.13)$ \\
\hline Size & $-0.09 * * *(-11.62)$ & $-0.09 * * *(-11.77)$ & $-0.09 * * *(-11.74)$ \\
\hline $\mathrm{AE}$ & $-0.36 * * *(-3.59)$ & $-0.33 * * *(-3.29)$ & $-0.33 * * *(-3.30)$ \\
\hline $\mathrm{B} / \mathrm{M}$ & $0.10 * * *(3.70)$ & $0.08 * * *(3.04)$ & $0.08 * * *(3.04)$ \\
\hline ROA & $-0.64 * * *(-6.19)$ & $-0.53 * * *(-5.23)$ & $-0.53 * * *(-5.20)$ \\
\hline Leverage & $0.32 * * *(6.50)$ & $0.32 * * *(6.39)$ & $0.32 * * *(6.41)$ \\
\hline LDebt & $0.26 * * *(11.90)$ & $0.26 * * *(12.20)$ & $0.26 * * *(12.21)$ \\
\hline Tangibility & $-0.42 * * *(-11.29)$ & $-0.40 * * *(-10.81)$ & $-0.40 * * *(-10.77)$ \\
\hline Liquidity & $-0.18 * * *(-3.09)$ & $-0.09(-1.52)$ & $-0.09(-1.49)$ \\
\hline Constant & $2.53 * * *(17.15)$ & $2.68 * * *(18.02)$ & $2.45 * * *(16.24)$ \\
\hline Industry fixed effects & Included & Included & Included \\
\hline Year fixed effects & Included & Included & Included \\
\hline Adjusted $\mathrm{R}^{2}$ & 0.35 & 0.36 & 0.36 \\
\hline Observations & 3194 & 3194 & 3194 \\
\hline
\end{tabular}

T-statistics are in parentheses, computed using the standard error with small-sample correction.

$*, * *$ and $* * *$ indicate significance at the $10 \%, 5 \%$ and $1 \%$ levels, respectively.

\subsubsection{Two-tier board structure and the use of collateral}

Table 6 provides the results of the collateral equation from our simultaneous equation system on the association between a two-tier board structure and the use of collateral. In first three 
columns, we examine the effect of proxies for the board of directors on the use of collateral. In particular, the estimated coefficients of Board and Duality are positive and statistically significant (t-values are 2.34 and 2.77, respectively), and significantly negative for Indep (tvalue is -2.05). The positive signs on Board and Duality indicate that firms with a larger board or dual CEO/chairman are more likely to pledge collateral in their loan contracts; while the negative sign on Indep indicates that firms with more independent directors are less likely to use collateral. We also observe that the estimated coefficients of Board*NonSOE and Duality*NonSOE are negative, and those for Indep*NonSOE are positive. These results support hypotheses $\mathrm{H} 2 \mathrm{a}, \mathrm{H} 2 \mathrm{~b}$, and $\mathrm{H} 2 \mathrm{c}$, and are consistent with our arguments that larger boards and dual CEO/chairman are associated with lower monitoring effectiveness of boards of directors, and that independent directors are able to exert an autonomous monitoring function and improve the corporate governance of firms; and that these effects are more pronounced in SOEs. Thus, banks are likely to reward borrowers with better governance by lowering collateral requirements. The result regarding the role of independent directors also corroborates the recent evidence provided by Liu et al. (2015), that board independence can improve firm performance in Chinese SOEs through effective monitoring.

Table 6. Effect of two-tier board structure on the use of collateral

\begin{tabular}{|c|c|c|c|c|c|c|}
\hline \multirow[t]{2}{*}{ Dependent variable } & \multicolumn{6}{|c|}{ Collateralized loan ratio } \\
\hline & 1 & 2 & 3 & 4 & 5 & 6 \\
\hline Board & $\begin{array}{l}0.06 * * \\
(2.34)\end{array}$ & & & & & $\begin{array}{l}0.09 * * \\
(2.16)\end{array}$ \\
\hline Board*NonSOE & $\begin{array}{l}-0.05 * * * \\
(-2.74)\end{array}$ & & & & & $\begin{array}{l}-0.08 * * \\
(-2.26)\end{array}$ \\
\hline Indep & & $\begin{array}{l}-0.09 * * \\
(-2.05)\end{array}$ & & & & $\begin{array}{l}-0.09 * * \\
(-1.97)\end{array}$ \\
\hline Indep*NonSOE & & $\begin{array}{l}0.06^{*} \\
(1.89)\end{array}$ & & & & $\begin{array}{l}0.07 * * \\
(2.06)\end{array}$ \\
\hline Duality & & & $\begin{array}{l}0.07 * * * \\
(2.77)\end{array}$ & & & $\begin{array}{l}0.07 * * * \\
(2.67)\end{array}$ \\
\hline Duality*NonSOE & & & $\begin{array}{l}-0.06^{*} \\
(-1.75)\end{array}$ & & & $\begin{array}{l}-0.06 * \\
(-1.71)\end{array}$ \\
\hline SB size & & & & $\begin{array}{l}-0.15^{* *} \\
(-2.45)\end{array}$ & & $\begin{array}{l}-0.10 * * * \\
(-2.74)\end{array}$ \\
\hline SB size*NonSOE & & & & $\begin{array}{l}0.02 * \\
(1.67)\end{array}$ & & $\begin{array}{l}0.02 * \\
(1.82)\end{array}$ \\
\hline SB expert & & & & & $\begin{array}{l}-0.03 * \\
(-1.82)\end{array}$ & $\begin{array}{l}-0.01 * * \\
(-2.37)\end{array}$ \\
\hline SB expert*NonSOE & & & & & $\begin{array}{l}-0.07 * * \\
(-2.25)\end{array}$ & $\begin{array}{l}-0.09 * * \\
(-2.50)\end{array}$ \\
\hline NonSOE & $\begin{array}{l}0.23 * * * \\
(3.60)\end{array}$ & $\begin{array}{l}0.14 * * * \\
(2.92)\end{array}$ & $\begin{array}{l}0.19 * * * \\
(12.03)\end{array}$ & $\begin{array}{l}0.10^{* *} \\
(2.51)\end{array}$ & $\begin{array}{l}0.19 * * * \\
(10.54)\end{array}$ & $\begin{array}{l}0.15^{*} \\
(1.88)\end{array}$ \\
\hline Excess & $\begin{array}{l}0.07 * * * \\
(2.86)\end{array}$ & $\begin{array}{l}0.05 * * \\
(2.60)\end{array}$ & $\begin{array}{l}0.06 * * * \\
(2.74)\end{array}$ & $\begin{array}{l}0.06 * * * \\
(2.76)\end{array}$ & $\begin{array}{l}0.06 * * \\
(2.75)\end{array}$ & $\begin{array}{l}0.06 * * \\
(2.79)\end{array}$ \\
\hline Top2_10 & $\begin{array}{l}-0.37 * * * \\
(-6.67)\end{array}$ & $\begin{array}{l}-0.35 * * * \\
(-6.40)\end{array}$ & $\begin{array}{l}-0.36 * * * \\
(-6.57)\end{array}$ & $\begin{array}{l}-0.35 * * * \\
(-6.40)\end{array}$ & $\begin{array}{l}-0.36 * * * \\
(-6.58)\end{array}$ & $\begin{array}{l}-0.36 * * * \\
(-6.40)\end{array}$ \\
\hline Ownership & $\begin{array}{l}-0.28 * * * \\
(-6.13)\end{array}$ & $\begin{array}{l}-0.28 * * \\
(-6.03)\end{array}$ & $\begin{array}{l}-0.28 * * * \\
(-6.13)\end{array}$ & $\begin{array}{l}-0.28 * * * \\
(-6.13)\end{array}$ & $\begin{array}{l}-0.28 * * * \\
(-6.27)\end{array}$ & $\begin{array}{l}-0.27 * * * \\
(-5.84)\end{array}$ \\
\hline
\end{tabular}




\begin{tabular}{|c|c|c|c|c|c|c|}
\hline Guarantee & $\begin{array}{l}-0.67 * * * \\
(-34.21)\end{array}$ & $\begin{array}{l}-0.67 * * * \\
(-34.28)\end{array}$ & $\begin{array}{l}-0.67 * * * \\
(-34.27)\end{array}$ & $\begin{array}{l}-0.68 * * * \\
(-34.30)\end{array}$ & $\begin{array}{l}-0.67 * * * \\
(-34.22)\end{array}$ & $\begin{array}{l}-0.67 * * * \\
(-34.26)\end{array}$ \\
\hline Size & $\begin{array}{l}-0.09 * * * \\
(-11.52)\end{array}$ & $\begin{array}{l}-0.08 * * * \\
(-11.34)\end{array}$ & $\begin{array}{l}-0.08 * * * \\
(-11.45)\end{array}$ & $\begin{array}{l}0.08 * * * \\
(-11.21)\end{array}$ & $\begin{array}{l}-0.08 * * * \\
(-11.38)\end{array}$ & $\begin{array}{l}-0.08 * * * \\
(-11.16)\end{array}$ \\
\hline $\mathrm{AE}$ & $\begin{array}{l}-0.34 * * * \\
(-3.35)\end{array}$ & $\begin{array}{l}-0.33 * * * \\
(-3.29)\end{array}$ & $\begin{array}{l}-0.33 * * * \\
(-3.30)\end{array}$ & $\begin{array}{l}-0.34 * * * \\
(-3.38)\end{array}$ & $\begin{array}{l}-0.33 * * * \\
(-3.30)\end{array}$ & $\begin{array}{l}-0.33 * * * \\
(-3.26)\end{array}$ \\
\hline $\mathrm{B} / \mathrm{M}$ & $\begin{array}{l}0.08 * * * \\
(3.00)\end{array}$ & $\begin{array}{l}0.08 * * * \\
(2.95)\end{array}$ & $\begin{array}{l}0.08 * * * \\
(3.08)\end{array}$ & $\begin{array}{l}0.08 * * * \\
(2.87)\end{array}$ & $\begin{array}{l}0.08 * * * \\
(2.97)\end{array}$ & $\begin{array}{l}0.08 * * * \\
(2.90)\end{array}$ \\
\hline ROA & $\begin{array}{l}-0.55 * * * \\
(-5.30)\end{array}$ & $\begin{array}{l}-0.53 * * * \\
(-5.12)\end{array}$ & $\begin{array}{l}-0.55^{* * *} \\
(-5.25)\end{array}$ & $\begin{array}{l}-0.55 * * * \\
(-5.32)\end{array}$ & $\begin{array}{l}-0.55 * * * \\
(-5.25)\end{array}$ & $\begin{array}{l}-0.52 * * * \\
(-5.09)\end{array}$ \\
\hline Lev & $\begin{array}{l}0.31 * * * \\
(6.32)\end{array}$ & $\begin{array}{l}0.32 * * * \\
(6.39)\end{array}$ & $\begin{array}{l}0.32 * * * \\
(6.45)\end{array}$ & $\begin{array}{l}0.32 * * * \\
(6.49)\end{array}$ & $\begin{array}{l}0.31 * * * \\
(6.37)\end{array}$ & $\begin{array}{l}0.33 * * * \\
(6.64)\end{array}$ \\
\hline Ldebt & $\begin{array}{l}0.27 * * * \\
(12.32)\end{array}$ & $\begin{array}{l}0.27 * * * \\
(12.42)\end{array}$ & $\begin{array}{l}0.27 * * * \\
(12.48)\end{array}$ & $\begin{array}{l}0.27 * * * \\
(12.38)\end{array}$ & $\begin{array}{l}0.27 * * * \\
(12.43)\end{array}$ & $\begin{array}{l}0.27 * * * \\
(12.49)\end{array}$ \\
\hline Tangibility & $\begin{array}{l}-0.40 * * * \\
(-10.81)\end{array}$ & $\begin{array}{l}-0.40 * * * \\
(-10.79)\end{array}$ & $\begin{array}{l}-0.39 * * * \\
(-10.72)\end{array}$ & $\begin{array}{l}-0.39 * * * \\
(-10.57)\end{array}$ & $\begin{array}{l}-0.40 * * * \\
(-10.82)\end{array}$ & $\begin{array}{l}-0.40 * * * \\
(-10.83)\end{array}$ \\
\hline Liquidity & $\begin{array}{l}-0.11^{*} \\
(-1.90)\end{array}$ & $\begin{array}{l}-0.11^{*} \\
(-1.81)\end{array}$ & $\begin{array}{l}-0.10^{*} \\
(-1.77)\end{array}$ & $\begin{array}{l}-0.11^{*} \\
(-1.81)\end{array}$ & $\begin{array}{l}-0.11^{*} \\
(-1.90)\end{array}$ & $\begin{array}{l}-0.11^{*} \\
(-1.87)\end{array}$ \\
\hline Constant & $\begin{array}{l}2.64 * * * \\
(17.26)\end{array}$ & $\begin{array}{l}2.61 * * * \\
(17.35)\end{array}$ & $\begin{array}{l}2.59 * * * \\
(17.62)\end{array}$ & $\begin{array}{l}2.56^{* * * *} \\
(17.02)\end{array}$ & $\begin{array}{l}2.62 * * * \\
(17.76)\end{array}$ & $\begin{array}{l}2.44 * * * \\
(16.01)\end{array}$ \\
\hline Industry fixed effects & Included & Included & Included & Included & Included & Included \\
\hline Year fixed effects & Included & Included & Included & Included & Included & Included \\
\hline Adjusted $\mathrm{R}^{2}$ & 0.36 & 0.36 & 0.36 & 0.36 & 0.36 & 0.37 \\
\hline Observations & 3194 & 3194 & 3194 & 3194 & 3194 & 3194 \\
\hline
\end{tabular}

T-statistics are in parentheses, computed using the standard error with small-sample correction.

$*$, **and *** indicate significance at the $10 \%, 5 \%$ and $1 \%$ levels, respectively.

Columns 4 and 5 examine the relationship between the structure of a supervisory board and the use of collateral. From these two columns, we observe that the estimated coefficients of both $S B$ size and $S B$ expert are negative and significant at the $10 \%$ or $5 \%$ levels (t-values are -2.45 and -1.82 ), respectively. These coefficients indicate that a larger supervisory board and its combined expertise can reduce the use of collateral in loan contracts by Chinese listed firms, which is partially consistent with hypotheses $\mathrm{H} 3 \mathrm{a}$ and $\mathrm{H} 3 \mathrm{~b}$. These results are consistent with the argument by Firth et al. (2007a) that larger supervisory boards with professional knowledge are effective in monitoring executives and directors, and therefore improve corporate governance. In columns 4 and 5, we also observe that the estimated coefficients of $S B$ size ${ }^{*}$ NonSOE and SB expert*NonSOE are positive and negative, respectively, suggesting that the effect of supervisory board is more pronounced in SOEs, while the effect of supervisory board expertise is more pronounced in non-SOEs.

Although this is inconsistent with our hypothesis $\mathrm{H} 3 \mathrm{~b}$, it could be consistent with the situation in China: The proposed explanation could be that, in China, non-SOEs usually face discrimination in accessing bank loans from state-owned banks (Cull and $\mathrm{Xu}, 2003$; Li et al., 2008), and so a professional supervisory board may help non-SOEs to improve accounting quality and alleviate the credit concern of banks, thus reducing the collateral requirements. 
The results in the last column, where we consider all variables together, are quantitatively similar to those reported in columns 1 to 5 .

The overall results from Tables 5 and 6 demonstrate our main findings, that the monitoring effectiveness of ownership and a two-tier board structure varies between SOEs and non-SOEs, which can be attributed to different dominant agency problems in these firms. Specifically, in SOEs, the controlling shareholder is the government, which is not a real person, resulting in an ambiguous identification of ultimate property rights; and managers are only the agents, so principal-manager conflicts of interest dominate in SOEs (Fan et al., 2013). Moreover, as the central government has decentralized decision rights and reduced government interference, the government's power to appoint or vote for directors for SOEs has diminished; and both boards of directors and supervisory boards have started to function properly to constrain managerial self-dealing, which may well reduce credit risks and the use of collateral. However, in non-SOEs, the controlling shareholders hold substantial controlling positions in management, so that controlling-minority shareholder conflicts of interest dominate in non-SOEs. As controlling shareholders still control the appointment of boards of directors and supervisory boards (Chen et al., 2006), monitoring by other block shareholders will be effective in reducing expropriation by controlling shareholders, and their influence becomes more significant for non-SOEs relative to SOEs.

\section{Additional tests}

\subsection{Identity of controlling shareholders and the use of collateral}

The previous sections differentiate firms as either SOEs or non-SOEs; and this may raise additional concerns about the identity of controlling shareholders for both SOEs and nonSOEs. On the one hand, the controlling shareholder of SOEs can be either the central government or local governments, which have different objectives. Specifically, central SOEs aim to maintain control over key industries and guarantee the safety of the national economy, while local SOEs aim to increase local GDP and reduce local unemployment (Jin et al., 2005). Chen et al. (2009) also argue that central SOEs are subject to stricter monitoring from the government compared with local SOEs. To examine the use of collateral between these two types of firms empirically, we include a dummy variable SOECG, which equals 1 for central SOEs and 0 for local SOEs, into the collateral equation; and estimate equations using the SOE subsample only. The results are reported in column 1 of Table 7.

On the other hand, for non-SOEs, the incentive of controlling shareholders to expropriate other investors may vary across different types of large owners (Lin et al., 2011). Firstly, 
within the sample of our non-SOEs, there are 4\% (57) firm-year observations that are widely held ownership firms. As no shareholder holds controlling positions, the incentive for expropriation in these firms may be weak, compared with the incentive for controlling shareholders. We thus re-estimate our baseline model by including a controlling shareholder identity dummy (Controlling). Secondly, for non-SOEs, the controlling shareholders can be divided into the following groups: family or individuals; financial institutions; and collective control. If the controlling shareholder is a financial institution or a collective, the private benefits of control are diluted among many independent owners; and as a result the controlling shareholder's incentive for tunnelling may be weak. If the controlling shareholder is an individual or a family, they could have a stronger incentive for expropriation, as the dilution of private benefits is not a problem (Villalonga and Amit, 2006; Ellul et al., 2007). Thus, we examine whether the use of collateral is even higher for particular types of controlling shareholders of non-SOEs. Empirically, we include controlling shareholder type identity (Family, Collective, Financial) into our baseline model, and run the regressions for the non-SOE subsamples and report the results in the last two columns of Table 7 (we only report the key variables that are of interest to us).

Table 7. Controlling shareholder identity and the use of collateral

\begin{tabular}{|c|c|c|c|}
\hline \multirow[t]{2}{*}{ Dependent variable } & \multicolumn{3}{|c|}{ Collateralized loan ratio } \\
\hline & 1.SOE subsample & 2.Non-SOE subsample & 3.Non-SOE subsample \\
\hline SOECG & $-0.04 * * *(-2.74)$ & & \\
\hline Controlling & & $0.04 * * *(2.95)$ & \\
\hline Family & & & $0.05 * *(2.09)$ \\
\hline Collective & & & $0.03(1.13)$ \\
\hline Financial & & & $0.01(0.38)$ \\
\hline \multicolumn{4}{|c|}{$\begin{array}{l}\text { Control variables include all corporate governance related variables and the other control variables that we use } \\
\text { in previous tables }\end{array}$} \\
\hline Adjusted $\mathrm{R}^{2}$ & 0.30 & 0.36 & 0.37 \\
\hline Observations & 1778 & 1416 & 1416 \\
\hline
\end{tabular}

As can be seen in the first column, the coefficient of SOECG is -0.04 and significant at the $1 \%$ level (t-value is -2.74). This result indicates that central SOEs place less collateral in their loan contracts compared with local SOEs. As can be seen in the last two columns, the estimated coefficient of Controlling is 0.04 and significant at the $1 \%$ level (t-value is 2.95), indicating that, compared with widely held firms, the presence of controlling shareholders is associated with higher use of collateral. In the last column, we find that the estimated coefficient of Family is significantly positive, while the coefficients of both Collective and Financial are insignificant. These results imply that, among different types of non-SOE 
owners, family (individual)-controlled firms are more likely to be required to pledge collateral compared with other types of firms.

\subsection{Robustness check}

Though we have addressed the issue of reverse causality using the simultaneous equation system, we may still face the issue of endogeneity due to unobserved time-invariant characteristics. To further address this issue and check the robustness of our main results, we estimate the collateral equation, which includes all of our key variables together, using the firm fixed effect model and system GMM; and report the results in Table 8. As can be seen, the results are broadly consistent with our results from previous tables. Specifically, for system GMM estimation, we also conduct the Hansen over-identification test and report the J-statistics (p-value). The J-statistics follow the Chi-square $\left(\chi^{2}\right)$ distribution under the null hypothesis that the instruments we use are exogenous. Table 8 shows that the p-value is 0.57 larger than 0.1, indicating that we cannot reject the null hypothesis. Moreover, $\operatorname{AR}(1)$ and $\mathrm{AR}(2)$ tests suggest that residuals are correlated in the first differences, but are not correlated in the second differences. These tests indicate the validity of our system GMM estimation. These results further confirm the findings from the preceding regression analyses.

In addition, we also notice that our main results may suffer the issue of selection bias, because it can be argued that the results that SOEs have a lower collateralized loan ratio could be due to the fact that banks are inclined to lend to SOEs so that SOEs receive more bank loans. Though we have presented consistent and robust results with alternative specifications that can address endogeneity to a large extent, we offer the caveat that we are not able to rule out the endogeneity issue completely, and thus caution should be exercised when interpreting our results.

Table 8. Effect of ownership structure and corporate governance on the use of collateral: Firm fixedeffects and System GMM

\begin{tabular}{lll} 
& 1. Firm fixed-effects & 2. System GMM \\
\hline Board & $0.09 * *(2.30)$ & $0.16^{* *(2.07)}$ \\
Indep & $-0.02(-0.57)$ & $-0.23^{* * *(-5.10)}$ \\
Duality & $0.08^{* *(2.43)}$ & $0.03(1.22)$ \\
SB size & $-0.07 * *(-2.09)$ & $-0.03 * *(-2.16)$ \\
SB expertise & $-0.06 *(-1.73)$ & $-0.04 *(-1.91)$ \\
NonSOE & $0.02(0.45)$ & $0.06(0.17)$ \\
Top2_10 & $-0.19 * *(-2.27)$ & $-0.47 * *(-4.09)$ \\
Excess & $0.02 *(1.74)$ & $0.01 * * *(7.13)$ \\
Hansen test (p-value) & & 0.57 \\
AR (1) (p-value) & & 0.00 \\
AR (2) (p-value) & & 0.47 \\
Adjusted R & & \\
Observations & 0.12 & 2052 \\
\hline
\end{tabular}


Note: all control variables are also included in both regressions, and the lagged dependent variable is also included in the system GMM regression.

In the fixed-effect regression, $t$-statistics are in parentheses, computed using the robust standard error, clustered by the firm. In the system GMM regressions, t-statistics are in parentheses, computed using the two-step robust, firm-clustered standard errors with small-sample correction.

$*$, **and $* * *$ indicate significance at the $10 \%, 5 \%$ and $1 \%$ levels, respectively.

\subsection{Alternative measurements and additional concern}

Our next test relates to alternative measurements. Larger firms may have more directors on boards and supervisory boards; and thus we apply two alternative variables in the regression for a robustness check. In particular, the new variables are defined as the ratio of the log of board size and supervisory board size to the log of total firm assets. We also redefine our Excess and Top2_10 variables, and create two new variables, Excess_dummy and Top2_10_dummy, which are dummy variables, equal to 1 if a firm has a control-ownership wedge or other large shareholders, and 0 otherwise. The results in column 1 of Table 9 show that using these alternative variables does not change the quality of the findings or the explanatory power of the model. In the untabulated analysis, we also use a Herfindahl index $(H E R F)$ of the second to the tenth largest shareholdings to capture the internal governance of other large shareholders. HERF is defined as the sum of the squares of the proportional shareholdings of the second to the tenth largest shareholders in the company; and the results remain unchanged. We also reclassify the variable Duality, by including those CEOs who are also vice-chairman or director. This alternative definition of duality yields similar results to those already reported when using the original definition.

Table 9. Alternative measures

\begin{tabular}{lll}
\hline & Table 9. Alternative measures \\
\hline Board $^{\text {a }}$ & 1.Alternative variables & 2. Ordered logit model \\
Indep & $0.12 * *(2.50)$ & $0.02 * *(2.44)$ \\
Duality & $-0.07 *(-1.91)$ & $-0.19 * *(-2.10)$ \\
SB size & $0.04 * *(2.05)$ & $0.07 *(1.69)$ \\
SB expertise & $-0.22 *(-1.95)$ & $-0.03 * *(-2.55)$ \\
NonSOE & $-0.06 * *(-2.11)$ & $-0.10^{* *(-2.38)}$ \\
Excess_dummy & $0.17 * * *(11.09)$ & $0.40 * *(10.73)$ \\
Top2_10_dummy & $0.02 * *(2.37)$ & $0.10 * *(2.06)$ \\
Control variables include cash flow rights, guarantee, firm size, AE, B/M, ROA, Leverage, LDebt, Tangibility, \\
Liquidity, industry and year fixed effects \\
Adjusted R ${ }^{2}$ & $-0.07 * * *(-5.19)$ & $-0.16 * *(-4.60)$ \\
Observations & 3194 & 0.37 \\
\hline
\end{tabular}

${ }^{\mathrm{a}}$ These variables are redefined in this regression analysis. In particular, Board is defined as the ratio of the log of the total number of directors on the board to the $\log$ of firm total assets; $S B$ size is defined as the ratio of the $\log$ of the total number of directors on the supervisory board to the log of firm total assets; Excess_dummy is defined as a dummy variable, equal to 1 if the firm has a control-ownership wedge and 0 otherwise; and Top2_10_dummy is defined as a dummy variable if the firm has other large shareholders and 0 otherwise.

$\mathrm{T}$-statistics are in parentheses, computed using the standard error with small-sample correction.

$*, * *$ and $* * *$ indicate significance at the $10 \%, 5 \%$ and $1 \%$ levels, respectively. 
We also use an alternative measure for collateral and construct ranks for the use of collateral, which can be based on 25 percentiles of the collateral variable. Hence, the continuous measure of the collateralized loan ratio is transformed into an ordinal variable with four ranks. To analyse a ranked dependent variable, we apply the Ordered Logit approach. Column 2 shows the result of the Ordered Logit models. The regression results are similar to those reported in previous tables, which suggests that the results are robust for the alternative specification.

Existing studies have also pointed out that board size and ownership structure exhibit a non-linear relationship with firm value and earnings management (Yermack, 1996; Ding et al., 2007); and thus board size and ownership by other large shareholders may demonstrate a non-linear shape with the use of collateral. In order to verify this concern, we have reestimated our main regression by including square terms of ownership structure and board size attributes separately. From the results (unreported here), we find that the estimated coefficients on the square terms are all insignificant, indicating that there does not exist any significant non-linear relationship between corporate governance, ownership, and the use of collateral.

\subsection{Corporate governance, related party transaction, and credit risks}

In the previous section, we found corporate governance to be an important determinant of the use of collateral. Our main conjecture is that good corporate governance is effective in alleviating expropriation by controlling shareholders and reducing firm credit risks, and in turn reduces collateral requirements by banks. However, although we have used excess control rights as the proxy for expropriation in the previous section and investigated its influence on the use of collateral, we have not provided any direct evidence relating to the above relationship between corporate governance and expropriation. Therefore, in this section, we present the results of more direct tests of these predictions by estimating the effects of corporate governance on more direct measures of expropriation. The first measure of expropriation is intercorporate loans (also called funds occupation), which is a primary tool used by controlling shareholders for tunnelling. Following Jiang et al. (2010), other receivables to total assets (ORECTA) are used to measure intercorporate loans to controlling shareholders. 
In China, listed firms are required to disclose the amount of transactions between related parties in their financial statements ${ }^{10}$. Following Cheung et al. (2006), Jian and Wong (2010) and Huyghebaert and Wang (2012), we also choose to use the related party transactions (RPTs) as an alternative measure for expropriation by controlling shareholders.

In the first column of Table 10, whether better corporate governance helps a firm prevent tunnelling is tested by using the other receivables deflated by total assets (ORECTA) as the dependent variable to measure tunnelling. The first regression shows that these variables of governance show expected coefficients similar to those reported previously, indicating that good governance indeed prevents tunnelling. For example, the estimated coefficient of Board is 0.003 , significant at the $10 \%$ level ( $\mathrm{t}$-value is 1.83 ), indicating that larger board size is less effective in constraining expropriation by controlling shareholders. We also observe that other corporate governance variables influence expropriation, consistent with their effects on the use of collateral in previous tables (except that the effect of Duality becomes insignificant). This finding, that governance helps a firm to prevent tunnelling through intercorporate loans, may partially explain why such governance affords firms certain advantages in reducing the use of collateral.

Table 10. Corporate governance, related party transaction and credit risks

\begin{tabular}{lccc}
\hline Dependent variable & 1. ORECTA & 2. RPTs & 3.ST status \\
\hline Board & $0.003^{*}(1.83)$ & $0.01 * *(2.32)$ & $0.02 * *(2.32)$ \\
Indep & $-0.003^{* *(-2.01)}$ & $-0.02 * *(-2.07)$ & $-0.02(-1.60)$ \\
Duality & $0.006(0.38)$ & $0.09 * *(2.56)$ & $0.01 * *(1.99)$ \\
SB size & $-0.010^{* *(-2.15)}$ & $-0.01(-1.30)$ & $-0.03 *(-1.93)$ \\
SB expertise & $-0.002 *(-1.74)$ & $-0.02 *(-1.83)$ & $-0.02 * *(-2.42)$ \\
NonSOE & $0.002(1.20)$ & $0.02(1.28)$ & $0.09 *(1.88)$ \\
Excess & $0.09 * *(2.03)$ & $0.03 * * *(4.55)$ & $0.01 * * *(4.59)$ \\
Top2_10 & $0.03(0.18)$ & $-0.23 * * *(-4.33)$ & $-0.17 * * *(-8.91)$ \\
Control variables from equation & $(1)$ are also included in each regression. & 0.05 \\
Adjusted R ${ }^{2} /$ Pseudo $\mathrm{R}^{2}$ & 0.08 & 0.10 & 3194 \\
Observations & 3194 & 3194 & \\
\hline
\end{tabular}

T-statistics/Z-statistics are in parentheses, computed using the standard error with small-sample correction. $*, * *$ and $* * *$ indicate significance at the $10 \%, 5 \%$ and $1 \%$ levels, respectively.

Column 2 reports the empirical findings where related party transactions are employed as the dependent variables. Overall, the main findings are largely consistent with previous results that good corporate governance is able to mitigate the incentives for expropriation by controlling shareholders. For example, we observe that board size is positively related to RPTs, indicating that expropriation could be mitigated by reducing the board size.

\footnotetext{
${ }^{10}$ Detailed disclosures are required within two working days after signing the contract if, for one party, the total amount of transactions between related parties is larger than 1,000,000 Renminbi (RMB) or 0.5 per cent of audited net assets, whichever is higher. Moreover, these dealings have to be approved by the general meeting of shareholders as soon as their size exceeds $10,000,000 \mathrm{RMB}$ or $5 \%$ of audited net assets.
} 
Column 3 reports the empirical results regarding the connection between corporate governance and credit risks. Perhaps the ideal proxy for credit risks is the credit ratings of the bonds issued. However, we only have limited information on credit ratings of the bonds issued by our sample firms. Instead, we use the probability of being flagged with ST (ST*) in subsequent years as the approximate proxy for credit risks ${ }^{11}$, following Qian and Yeung (2015). The signs of our key variables are consistent with those reported in previous tables, indicating that better corporate governance is able to reduce the credit risks.

\section{Conclusions}

Using a sample of China's listed firms between 2007 and 2009, we investigated the effect of ownership and corporate governance on the firms' use of collateral in their loan contracts. We find that the use of collateral is higher for firms in which controlling shareholders have larger excess control rights or a lower proportion of ownership held by other large shareholders; which is more amplified in non-SOEs. Further analysis shows that governance by two-tier boards also matters for firms' use of collateral. In particular, we find that the use of collateral is higher for firms with larger board size, fewer independent directors, duality of CEO and chairman, and smaller supervisory board size; and that this is more pronounced in SOEs. In addition, the benefits of employing professional experts on the supervisory board are more significant for non-SOEs. Our results are robust to endogeneity using different estimation methods, including the simultaneous equation system, firm fixed effect model, and system GMM. Nevertheless, we raise the caveat that we cannot rule out endogeneity completely. Overall, these results suggest that the effectiveness of corporate governance on reducing the use of collateral depends on the type of controlling shareholders, as well as the dominating agency problem.

From the perspective of policy makers, the results suggest that listed firms should encourage other large shareholders to increase their ownership or reduce the excess control rights by the controlling shareholders, in exchange for more favourable loan contracts. The empirical results in this research also echo the measures taken by the authorities to encourage better corporate governance of listed firms by recommending changes in the two-tier board structure, which is of great importance in protecting banks. For example, we provide support for recent regulatory and listing requirements (see the newly amended Chinese Corporate

\footnotetext{
${ }^{11}$ ST stands for "Special Treatment", which is an indication of listed firms' irregular financial statements. In particular, a listed firm is flagged with ST if it has negative profits for two consecutive years. This measure can indicate that a firm has a higher credit risk.
} 
Law 2005) concerning more actively involved and professional boards of supervisors, with the evidence that more professional supervisors are associated with lower collateral pledged. 
Appendix.

Estimation results of other equations from the simultaneous equation system (corresponding to the collateral equation in column 3 of Table 6)

\begin{tabular}{|c|c|c|c|c|c|c|}
\hline & Board size & Independent & Excess & Top2_10 & Guarantee & ROA \\
\hline Collateral & $\begin{array}{l}0.27 * * \\
(2.16)\end{array}$ & $\begin{array}{l}-0.05 * * * \\
(-2.76)\end{array}$ & $\begin{array}{l}-0.09 * * * \\
(-4.30)\end{array}$ & $\begin{array}{l}-0.03 * * * \\
(-2.99)\end{array}$ & $\begin{array}{l}-0.56 * * * \\
(-28.74)\end{array}$ & $\begin{array}{l}-0.05 * * * \\
(-4.93)\end{array}$ \\
\hline Board & & $\begin{array}{l}0.07 \\
(0.92)\end{array}$ & $\begin{array}{l}-0.02 * \\
(1.84)\end{array}$ & $\begin{array}{l}0.08 * * * \\
(4.87)\end{array}$ & $\begin{array}{l}0.01 \\
(0.24)\end{array}$ & $\begin{array}{l}0.02 * * \\
(2.08)\end{array}$ \\
\hline Indep & $\begin{array}{l}-0.75 * * * \\
(-2.98)\end{array}$ & & $\begin{array}{l}0.46^{* * * *} \\
(4.75)\end{array}$ & $\begin{array}{l}2.57 * * \\
(2.26)\end{array}$ & $\begin{array}{l}-0.05 \\
(-1.42)\end{array}$ & $\begin{array}{l}0.03 * * * \\
(3.76)\end{array}$ \\
\hline Duality & $\begin{array}{l}-0.24 * \\
(-1.93)\end{array}$ & $\begin{array}{l}-0.01 \\
(-0.83)\end{array}$ & $\begin{array}{l}-0.06 \\
(-1.19)\end{array}$ & $\begin{array}{l}0.02 \\
(0.16)\end{array}$ & $\begin{array}{l}0.06 \\
(0.32)\end{array}$ & $\begin{array}{l}-0.01 \\
(-0.34)\end{array}$ \\
\hline SB size & $\begin{array}{l}0.37 * * * \\
(8.63)\end{array}$ & $\begin{array}{l}-0.01 \\
(-1.17)\end{array}$ & $\begin{array}{l}0.03 \\
(1.59)\end{array}$ & $\begin{array}{l}-0.05 \\
(-1.22)\end{array}$ & $\begin{array}{l}-0.07 \\
(-1.11)\end{array}$ & $\begin{array}{l}0.01 \\
(0.68)\end{array}$ \\
\hline SB expertise & $\begin{array}{l}-0.25 * * \\
(-2.11)\end{array}$ & $\begin{array}{l}0.08 * * * \\
(4.13)\end{array}$ & $\begin{array}{l}-0.05 * * * \\
(-4.60)\end{array}$ & $\begin{array}{l}-0.17 * * \\
(-2.49)\end{array}$ & $\begin{array}{l}-0.01 \\
(-0.38)\end{array}$ & $\begin{array}{l}0.01 * \\
(1.73)\end{array}$ \\
\hline NonSOE & $\begin{array}{l}0.66 * * * \\
(5.51)\end{array}$ & $\begin{array}{l}-0.02 * \\
(-1.85)\end{array}$ & $\begin{array}{l}0.07 * * * \\
(12.49)\end{array}$ & $\begin{array}{l}0.48 * * * \\
(6.09)\end{array}$ & $\begin{array}{l}0.08 * * * \\
(4.59)\end{array}$ & $\begin{array}{l}0.01 * \\
(1.89)\end{array}$ \\
\hline Top2_10 & $\begin{array}{l}0.34 * * * \\
(4.97)\end{array}$ & $\begin{array}{l}0.08 \\
(1.28)\end{array}$ & $\begin{array}{l}-0.08 * * * \\
(-5.18)\end{array}$ & & $\begin{array}{l}-0.36 * * * \\
(-6.03)\end{array}$ & $\begin{array}{l}0.05^{* *} \\
(2.32)\end{array}$ \\
\hline Excess & $\begin{array}{l}0.02 * * \\
(2.01)\end{array}$ & $\begin{array}{l}0.03 \\
(0.66)\end{array}$ & & $\begin{array}{l}-0.02 * * * \\
(-5.18)\end{array}$ & $\begin{array}{l}0.02 * * \\
(2.04)\end{array}$ & $\begin{array}{l}-0.00 \\
(-0.17)\end{array}$ \\
\hline Segment & $\begin{array}{l}0.15 * * \\
(2.23)\end{array}$ & & & & & \\
\hline Firm age & & $\begin{array}{l}0.03 * * \\
(2.16)\end{array}$ & & & & \\
\hline $\begin{array}{l}\text { Industry average } \\
\text { excess control rights }\end{array}$ & & & $\begin{array}{l}0.18 * * \\
(2.52)\end{array}$ & & & \\
\hline $\begin{array}{lr}\text { Industry } & \text { average } \\
\text { other } & \text { large } \\
\text { shareholding } & \end{array}$ & & & & $\begin{array}{l}0.68 * * \\
(2.19)\end{array}$ & & \\
\hline Lagged Guarantee & & & & & $\begin{array}{l}0.06 * * \\
(1.99)\end{array}$ & \\
\hline Lagged ROA & & & & & & $\begin{array}{l}0.45 * * * \\
(8.12)\end{array}$ \\
\hline $\begin{array}{l}\text { Over-identification } \\
\text { test }\end{array}$ & 0.67 & 0.51 & 0.43 & 0.50 & 0.41 & 0.33 \\
\hline Adjusted $\mathrm{R}^{2}$ & 0.23 & 0.31 & 0.23 & 0.27 & 0.32 & 0.26 \\
\hline Observations & 3194 & 3194 & 3194 & 3194 & 3194 & 3194 \\
\hline
\end{tabular}

The table reports the estimation results of other equations of the simultaneous equation system, corresponding to the collateral equation in column 3 of Table 6 . Only key variables as well as the instrument variables are reported. P-values are also reported for over-identification tests for examining the exogeneity of instrument variables. T-statistics are in parentheses, computed using the standard error with small-sample correction. $*, * *$ and $* * *$ indicate significance at the $10 \%, 5 \%$ and $1 \%$ levels, respectively. 


\section{Reference}

Almeida, H., Campello, M., 2007. Financial constraints, asset tangibility and corporate investment. Review of Financial Studies 20(5), 1429-1460.

An, C., Pan, X., Tian, G., 2014. Ownership structure and collateral requirements: Evidence from China's listed firms. International Review of Financial Analysis 36, 168-178.

Anderson, R., Mansi, S., Reeb, D., 2004. Board characteristics, accounting repot integrity and the cost of debt. Journal of Accounting and Economics 37, 315-342.

Ashbaugh-Skaife, H., Collins, D., LaFond, R., 2006. The effects of corporate governance on firms' credit ratings. Journal of Accounting and Economics 42, 203-243.

Bai, C., Liu, Q., Lu, J., Song, F.M. Zhang, J., 2004. Corporate governance and market valuation in China. Journal of comparative economics 32 (4), 599-616.

Barclay, M.J., Smith, C.W., 1995. The priority structure of corporate liabilities. The Journal of Finance 50(3), 899-916.

Bennedsen, M., Wolfenzon, D., 2000. The balance of power in closely held corporations. Journal of Financial Economics 58, 113-139.

Berkman, H., Cole, R., Fu, L., 2009. Expropriation through loan guarantees to related parties: Evidence from China. Journal of Banking and Finance 33 (1), 141-156.

Besanko, D., Thakor, A. V., 1987. Collateral and rationing: sorting equilibria in monopolistic and competitive credit markets. International Economic Review 28, 671-689.

Bhagat, S., Bolton, B., 2008. Corporate governance and firm performance. Journal of Corporate Finance 14(3), 257-273.

Bhabra, H.S., Liu, T., Tirtiroglu, D., 2008. Capital structure choice in a nascent market: Evidence from listed firms in China. Financial Management 37 (2), 341-364.

Boubakri, N., Ghouma, H., 2010. Control/ownership structure, creditor rights protection, and the cost of debt financing: International evidence. Journal of Banking and Finance 34, 24812499.

Brandt, L. Li, H. B., 2003. Bank discrimination in transition economies: Ideology, information, or incentives? Journal of Comparative Economics, 31, 387-413.

Cao, J., Pan, X., Tian, G., 2011. Disproportional ownership structure and pay-performance relationship: Evidence from China's listed firms. Journal of Corporate Finance 17(2), 541554.

Chen, G., Firth, M., Gao, D.N., Rui, O.M., 2006. Ownership structure, corporate governance, and fraud: Evidence from China. Journal of Corporate Finance 12 (3), 424-448. 
Chen, G., Firth, M., Xu, L., 2009. Does the type of ownership control matter? Evidence from China's listed companies. Journal of Banking and Finance 33, 171-181.

Chen, S., Sun, Z., Tang, S., Wu, D., 2011. Government intervention and investment efficiency: Evidence from China. Journal of Corporate Finance 17, 259-271.

Chen, J.Z., Lobo, G.J., Wang, Y., Yu, L., 2013. Loan collateral and financial reporting conservatism: Chinese evidence. Journal of Banking and Finance 37 (12), 4989-5006.

Cheung, Y., Rau, P.R., Stouraitis, A., 2006. Tunneling, propping, and expropriation: Evidence from connected party transactions in Hong Kong. Journal of Financial Economics 82 (2), 343-386.

China Securities Regulatory Commission (CSRC), 2002. Code of corporate governance for listed companies. (In Chinese).

Claessens, S., Djankov, S., Fan, J. P. H., Lang, L.H.P., 2002. Disentangling the incentive and entrenchment effects of large shareholdings. Journal of Finance 57, 2741-2771.

Company Law, 2003. Company Law. Amended at the $18^{\text {th }}$ Session of the Standing Committee of the $10^{\text {th }}$ National People's Congress on $27^{\text {th }}$ October 2005.

Cull, R., Xu, L., 2003. Who gets credit? The behaviour of bureaucrats and state banks in allocating credit to Chinese state-owned enterprises. Journal of Development Economics 71, 533-559.

Dahya, J., Karbhari, Y., Xiao, J.Z., Yang, M., 2003. The usefulness of the supervisory board report in China. Corporate governance: An international review 11 (4), 308-321.

Ding, S., Wu, Z., Li, Y., Jia, C., 2009. Can the Chinese two-tier-board system control the board chair pay? Asian Journal of Finance and Accounting 1 (1), 1-22.

Ding, Y., Zhang, H., Zhang, J., 2007. Private vs state ownership and earnings management: Evidence from Chinese listed companies. Corporate Governance: An International Review $15(2), 223-238$.

Ellul, A., Guntay, L., Lel, U., 2007. External governance and debt agency costs of family firms. International Finance Discussion Paper.

Fama, E., Jensen, M. C., 1983. Agency problem and residual claims. Journal of Law and Economics, 26: 327-349.

Fan, J., Wong, T.J., Zhang, T., 2013. Institutions and organizational structure: The case of state-owned corporate pyramids. Journal of Law, Economics, and Organization 29(6), 1217 1252. 
Firth, M., Fung, P.M.Y., Rui, O.M., 2007a. Ownership, two-tier board structure, and the informativeness of earnings: Evidence from China. Journal of Accounting and Public Policy 26 (4), 463-496.

Firth, M., Fung, P.M.Y., Rui, O.M., 2007b. How ownership and corporate governance influence chief executive pay in China's listed firms. Journal of Business Research 60 (7), 776-785.

Firth, M., Lin, C., Liu, P., Wong, S. M. L., 2009. Inside the black box: Bank credit allocation in China's private sector. Journal of Banking and Finance 33, 1144-1155.

Francis, B., Hasan, I., Song, L., 2012. Are firm- and country-specific governance substitutes? Evidence from financial contracts in emerging markets. Journal of Financial Research 35 (3), 343-374.

Ge, W., Kim, J., Song, B.Y., 2012. Internal governance, legal institutions and bank loan contracting around the world. Journal of Corporate Finance 18 (3), 413-432.

Huyghebaert, N., Wang, L., 2012. Expropriation of minority investors in Chinese listed firms: The role of internal and external corporate governance mechanisms. Corporate governance: An International Review 20 (3), 308-332.

Jackling, B., Johl, S., 2009. Board structure and firm performance: Evidence from India's top companies. Corporate Governance: An International Review 17(4), 492-509.

Jian, M., Wong, T., 2010. Propping through related party transactions. Review of Accounting Studies 15, 70-105.

Jiang, G., Lee, C.M.C., Yue, H., 2010. Tunneling through intercorporate loans: The China experience. Journal of Financial Economics 98 (1), 1-20.

Jin, H., Qian, Y., Weingast, B. R., 2005. Regional decentralization and fiscal incentives: federalism Chinese style. Journal of Public Economics 89, 1719-1742.

Koivu, T., 2009. Has the Chinese economy become more sensitive to interest rates? Studying credit demand in China. China economic review 20 (3), 455-470.

Laeven, L., Levine, R., 2008. Complex ownership structures and corporate valuations. Review of Financial Studies 21(2), 579-604.

Larcker, D.F., Richardson, S.A., Tuna, I., 2007. Corporate governance, accounting outcomes, and organizational performance. Accounting Review 82 (4), 963-1008.

Li, H. B., Meng, L., Wang, Q., Zhou, L., 2008. Political connections, financing and firm performance: Evidence from Chinese private firms. Journal of Development Economics 87, 283-299. 
Lin, C., Ma, Y., Malatesta, P., Xuan, Y., 2011. Ownership structure and the cost of corporate borrowing. Journal of Financial Economics 100, 1-23.

Linck, J., Netter, J., Yang, T., 2008. The determinants of board structure. Journal of Financial Economics 87(2), 308-328.

Liu, Q., 2006. Corporate governance in China: Current practices, economic effects and institutional determinants. CESifo Economic Studies 52(2), 415-453.

Liu, Q., Lu, Z., 2007. Corporate governance and earnings management in the Chinese listed companies: A tunneling perspective. Journal of Corporate Finance 13 (5), 881-906.

Liu, Y., Miletkov, M., Wei, Z., Yang, T., 2015. Board independence and firm performance in China. Journal of Corporate Finance 30, 223-244.

Menkhoff, L., Neuberger, D., Rungruxsirivorn, O., 2012. Collateral and its substitutes in emerging markets' lending. Journal of Banking and Finance 36 (3), 817-834.

Menkhoff, L., Neuberger, D., Suwanaporn, C., 2006. Collateral-based lending in emerging markets: Evidence from Thailand. Journal of Banking and Finance 30 (1), 1-21.

Podpiera, R., 2006. Progress in China's banking sector reform: Has bank behavior changed?

Working Paper, International Monetary Fund.

Qian, M., Yeung, B., 2015. Bank financing and corporate governance. Journal of Corporate Finance 32, 258-270.

Shan, Y., McIver, R., 2011. Corporate governance mechanisms and financial performance in China: Panel data evidence on listed non financial companies. Asia Pacific Business Review 17(3), 301-324.

Shan, Y.G., 2013. Can internal governance mechanisms prevent asset appropriation? Examination of Type I tunneling in China. Corporate Governance: An International Review $21(3), 225-241$.

Shleifer, A., Vishny, R., 1997. A survey of corporate governance. The Journal of Finance 52(2), 737-783.

Villalonga, B., Amit, R., 2006. How do family ownership, control and management affect firm value? Journal of Financial Economics 80, 385-417.

Wu, S., Xu, N., Yuan, Q., 2009. State control, legal investor protection, and ownership concentration: Evidence from China. Corporate Governance: An International Review 17 (2), 176-192.

Yang, J. Y., Qian, H., 2008. Survey evidence on commercial bank mortgage loans. Journal of Financial Research 333, 79-87 (in Chinese). 
Yeh, Y., Woidtke, T., 2005. Commitment or entrenchment? Controlling shareholders and board composition. Journal of Banking and Finance 29 (7), 1857-1885.

Yermack, D., 1996. Higher market valuation of companies with a small board of directors. Journal of Financial Economics 40, 185-211.

Yeung, G. 2009. How banks in China make lending decisions, Journal of Contemporary China, 18(59), 285-302. 